\title{
Beta-nodavirus B2 protein induces hydrogen peroxide production, leading to Drp1-recruited mitochondrial fragmentation and cell death via mitochondrial targeting
}

\author{
Yu C. Su $\cdot$ Hsuan W. Chiu $\cdot$ Jo C. Hung $\cdot$ \\ Jiann R. Hong
}

Published online: 10 July 2014

(C) The Author(s) 2014. This article is published with open access at Springerlink.com

\begin{abstract}
Because the role of the viral B2 protein in the pathogenesis of nervous necrosis virus infection remains unknown, the aim of the present study was to determine the effects of B2 protein on hydrogen peroxide $\left(\mathrm{H}_{2} \mathrm{O}_{2}\right)$-mediated cell death via mitochondrial targeting. Using a $\mathrm{B} 2$ deletion mutant, the B2 mitochondrial targeting signal sequence $\left({ }^{41}\right.$ RTFVISAHAA $\left.{ }^{50}\right)$ correlated with mitochondrial free radical production and cell death in fish cells, embryonic zebrafish, and human cancer cells. After treatment of grouper fin cells (GF-1) overexpressing B2 protein with the anti-oxidant drug, $N$-acetylcysteine (NAC), and overexpression of the antioxidant enzymes, $\mathrm{zfCu} / \mathrm{Zn}$ superoxide dismutase (SOD) and zfCatalase, decreased $\mathrm{H}_{2} \mathrm{O}_{2}$ production and cell death were observed. To investigate the correlation between $\mathrm{B} 2$ cytotoxicity and $\mathrm{H}_{2} \mathrm{O}_{2}$ production in vivo, $\mathrm{B} 2$ was injected into zebrafish embryos. Cell damage, as assessed by the acridine orange assay, gradually increased over $24 \mathrm{~h}$ post-fertilization, and was accompanied by marked increases in $\mathrm{H}_{2} \mathrm{O}_{2}$ production and embryonic death. Increased oxidative stress, as evidenced by the up-regulation of Mn SOD, catalase, and Nrf2, was also observed during this period. Finally, B2-induced dynamin-related protein 1 (Drp1)-mediated mitochondrial fragmentation and cell death could be reversed by NAC and inhibitors of Drp1 and Mdivi in GF-1 cells. Taken together, betanodavirus $\mathrm{B} 2$ induces $\mathrm{H}_{2} \mathrm{O}_{2}$ production via targeting the mitochondria, where it inhibits complex II function. $\mathrm{H}_{2} \mathrm{O}_{2}$ activates Drp1, resulting in its association
\end{abstract}

Y. C. Su · H. W. Chiu · J. C. Hung · J. R. Hong $(\bowtie)$ Laboratory of Molecular Virology and Biotechnology, Institute of Biotechnology, National Cheng Kung University, Tainan 701, Taiwan, ROC

e-mail: jrhong@mail.ncku.edu.tw with the mitochondria, mitochondrial fission and cell death in vitro and in vivo.

Keywords Anti-oxidants - Cell death · Hydrogen peroxide production - Mitochondrial fragmentation . Nervous necrosis virus - Oxidative stress

\section{Introduction}

Betanodavirus infection causes viral nervous necrosis (VNN) in fish, which is an infectious neuropathological condition characterized by necrosis of the central nervous system, including the brain and retina [1]. Clinical signs include abnormal swimming behavior and darkening of the fish [2]. VNN can induce massive death of the larval and juvenile populations of several marine teleost species [3]. However, little is known about the molecular pathogenesis of VNN.

The nodavirus genome comprises two single-stranded molecules of positive polarity, RNA1 and RNA2 that are approximately 3.1 and $1.4 \mathrm{~kb}$ in length, respectively [4]. RNA1 encodes a nonstructural protein of approximately 110-kDa, designated RNA-dependent RNA polymerase or protein A that is vital for replication of the viral genome [4]. RNA2 encodes a $42-\mathrm{kDa}$ capsid protein $[4,5]$ that may induce post-apoptotic necrotic cell death through a pathway mediated by cytochrome $c$ release [6]. During RNA replication, betanodaviruses synthesize a sub-genomic RNA3 from the $3^{\prime}$ terminus of RNA1 that encodes two non-structural proteins, B1 and B2 [1, 7, 8]. In red-spotted grouper nervous necrosis virus (RGNNV), B1 has anti-necrosis functions [9]; B2 acts as a host siRNA silencing suppressor in alphanodavirus [10-12] and betanodavirus [7].

Oxidative stress has been implicated in the pathogenesis of neurodegenerative diseases, such as Alzheimer's and 
Parkinson's diseases [13, 14]. Oxidative stress occurs in cells when production of reactive oxygen species (ROS) exceeds the cell's endogenous antioxidant defenses [15]. The major cellular defenses against ROS include superoxide dismutases (SODs) and catalase [16, 17]. SODs catalyze the dismutation of superoxide $\left(\mathrm{O}_{2}{ }^{-}\right)$to hydrogen peroxide $\left(\mathrm{H}_{2} \mathrm{O}_{2}\right)$ and molecular oxygen $\left(\mathrm{O}_{2}\right)$ and are located in the cytoplasm $(\mathrm{Cu} / \mathrm{Zn} \mathrm{SOD})$ and mitochondria (Mn SOD) [18, 19].

The induction of apoptosis and post-apoptotic necrotic cell death mediated by mitochondrial membrane potential loss and cytochrome c release by the RGNNV TN1 strain in fish cells was first identified by Chen et al. [20]. Necrosis was blocked by the mitochondrial membrane permeability transition pore inhibitor, bongkrekic acid (BKA) [20], the antiapoptotic Bcl-2 family member protein, zfBcl-xL [9], and the protein synthesis inhibitor, cycloheximide [21], suggesting that necrosis requires the synthesis of new protein. In addition, b2 protein can induce Bax-mediated cell death [12] and cause ATP depletion via blocking complex II function [22]. B2-induced Bax-mediated necrotic cell death can be blocked by overexpression of zfBcl-xL [8, 12]. Furthermore, we recently found that the RGNNV TN1 strain can induce ROS production, triggering the oxidative stress response [23]. However, the reason for this observation remains unknown. Therefore, this study aimed to elucidate the role of the $\mathrm{B} 2$ protein in the pathogenesis of betanodavirus infection in fish. In particular, we investigated the effects of B2 protein on oxidative stress-mediated cell death via mitochondrial targeting in vitro and in vivo.

\section{Materials and methods}

Cells

The grouper cell line, GF-1, was obtained from Dr. Chi (Institute of Zoology and for the Development of Life Science, Taiwan, ROC). Cells were maintained at $28{ }^{\circ} \mathrm{C}$ in Leibovitz's L-15 medium (GibcoBRL, Gaithersburg, MD, USA) supplemented with $5 \%$ fetal bovine serum (GeneDireX, San Diego, CA, USA) and $25 \mu \mathrm{g} / \mathrm{mL}$ gentamycin (GibcoBRL). Human embryonic kidney cell line (293T cells), epithelial cervical cancer cells (HeLa cells), breast adenocarcinoma cells (MCF7 cells), lung adenocarcinoma cells (A549 cells and H1299 cells) were grown at $37{ }^{\circ} \mathrm{C}$ in low glucose Dulbecco's modified Eagle's medium (DMEM, GibcoBRL) supplemented with $10 \%$ fetal bovine serum and $5 \% \mathrm{CO}_{2}$.

Plasmid construction and cell transfection

The B2 coding sequence and mitochondrial targeting signal deletion fragments were cloned into the p3XFlag-myc-
Table 1 The sequence primers used in this study

\begin{tabular}{|c|c|}
\hline Name & Primers $^{\mathrm{a}}$ \\
\hline \multicolumn{2}{|c|}{ pEYFP-B2(1-70) } \\
\hline Forward & GAAGATCTATGGAACAAATCCAACAA (BglII) \\
\hline Reverse & GGAATTCCTAGTCCGTCTCCATCGG (EcoRI) \\
\hline \multicolumn{2}{|c|}{ pEYFP-B2 $(\Delta)$} \\
\hline Forward 1 & GAAGATCTATGGAACAAATCCAACAA (BglII) \\
\hline Reverse 1 & GGAATTCCTACATCTCGTTTACCTGGAT (EcoRI) \\
\hline Forward 2 & GGAATTCGCTCGCCGCCTGCACGTC (EcoRI) \\
\hline Reverse 2 & CGGGATCCCTAGTCCGTCTCCATCGG $($ BamHI) \\
\hline \multicolumn{2}{|c|}{ p3XFLAG-B2 } \\
\hline Forward & GAAGATCTGATGGAACAAATCCAACAA (BglII) \\
\hline Reverse & CGGGATCCCTAGTCCGTCTCCATCGG $($ BamHI) \\
\hline \multicolumn{2}{|c|}{$\mathrm{p} 3 \mathrm{XFLAG}-\mathrm{B} 2(\Delta)$} \\
\hline Forward & GAAGATCTGATGGAACAAATCCAACAA (BglII) \\
\hline Reverse & CGGGATCCCTAGTCCGTCTCCATCGG $($ BamHI) \\
\hline \multicolumn{2}{|l|}{ zfCatalase } \\
\hline Forward & TAAAGGAGCAGGAGCGTTTGGCTA \\
\hline Reverse & TTCACTGCGAAACCACGAGGATCT \\
\hline \multicolumn{2}{|l|}{ zfMn SOD } \\
\hline Forward & CCGGACTATGTTAAGGCCATCT \\
\hline Reverse & ACACTCGGTTGCTCTCTTTTCTCT \\
\hline \multicolumn{2}{|l|}{ zfNrf2 } \\
\hline Forward & GAGCGGGAGAAATCACACAGAATG \\
\hline Reverse & CAGGAGCTGCATGCACTCATCG \\
\hline \multicolumn{2}{|l|}{ zfGAPDH } \\
\hline Forward & CCAGGTTGTGTCCACTGACTT \\
\hline Reverse & CATGTAATTTCCTTCCAGGCA \\
\hline \multicolumn{2}{|c|}{ zfCu/Zn SOD } \\
\hline Forward & GTCGTCTGGCTTGTGGAGTG \\
\hline Reverse & TGTCAGCGGGCTAGTGCTT \\
\hline
\end{tabular}

a The enzymatic cutting sites on nucleotides of primers are underlined

CMV-26 (Sigma, St. Louis, MO, USA) or pEYFP-C1 (Clontech Laboratories, Mountain View, CA, USA) vectors, and sequenced to verify the reading frame as previously described [22] (Table 1).

For cell transfection, $3 \times 10^{5} \mathrm{GF}-1$ cells were seeded in $60-\mathrm{mm}$ diameter culture dishes. On the following day, $2 \mu \mathrm{g}$ of recombinant plasmid was mixed with Lipofectamine 2000 (Invitrogen, Carlsbad, CA, USA), and the transfection procedure was carried out according to the manufacturer's instructions.

\section{Western blot analysis}

GF-1 cells were seeded in 60-mm diameter culture dishes with $3 \mathrm{~mL}$ medium $\left(10^{5}\right.$ cells $\left./ \mathrm{mL}\right)$. At the end of each incubation period, the culture medium was aspirated, and the cells were washed with PBS and then lysed in $0.3 \mathrm{~mL}$ 
of lysis buffer (10 mM Tris, pH 6.8, $20 \%$ glycerol, $10 \mathrm{mM}$ sodium dodecyl sulfate (SDS) [24], $2 \%$ ß-mercaptoethanol). An aliquot of each lysate with $30 \mu \mathrm{g}$ protein per sample was separated by electrophoresis on an SDS polyacrylamide gel to resolve the proteins. The gels were immunoblotted with the following antibodies: (1) anti-Flag primary monoclonal antibodies (1:8,000 dilution; Sigma) followed by peroxidase-labeled goat anti-mouse secondary antibodies (1:15,000 dilution; Amersham Biosciences, Piscataway, NJ, USA) or (2) human anti-Dynamin 1-like protein (Drp1) or voltage-dependent anion channels (VDAC) primary polyclonal antibodies (1:1,500 dilution; Novus Biologicals, Littleton, CO, USA) followed by a peroxidase-labeled goat anti-rabbit secondary antibodies (1:7,500 dilution; Amersham Biosciences, Piscataway, NJ, USA). Chemiluminescence indicative of antibody binding was captured on Kodak XAR- 5 films (Eastman Kodak, New York, USA) as previously described [25].

ROS production in intact cells

ROS levels were determined in living cells using the Image-iT LIVE Green Reactive Oxygen Species Detection Kit (Molecular Probes, Eugene, OR, USA), which uses carboxy- $\mathrm{H}_{2}$ DCFDA (5-[and-6-]-carboxy-2', $7^{\prime}$-dichlorodihydrofluorescein diacetate) staining, a reliable fluorogenic marker of ROS formation in live cells. Cells cultured in 60-mm diameter dishes were transfected with Flag, FlagB2, or Flag-B2 $\Delta$ for 48 and $72 \mathrm{~h}$. After the cells were gently washed once with PBS, $500 \mu \mathrm{L}$ of a working solution of $25 \mu \mathrm{M}$ carboxy- $\mathrm{H}_{2}$ DCFDA (Life Technologies, Carlsbad, CA, USA) in PBS was added to the cells and incubated in the dark for $30 \mathrm{~min}$. The samples were examined immediately under a fluorescence microscope with $100 \mathrm{~W}$ halogen for $0.5 \mathrm{~s}$ using the following bandpass filters: 488-nm excitation and 515-nm long-pass filter for detection of the fluorescein. The percentage of 200 cells at each time point was determined in triplicate, with each point representing the mean of three independent experiments.

To assess the total fluorescence, cells cultured on 6-well plates for 48 and $72 \mathrm{~h}$ post-transfection were incubated in the dark for $30 \mathrm{~min}$ with $350 \mu \mathrm{L}$ of $25 \mu \mathrm{M}$ carboxy- $\mathrm{H}_{2}$ DCFDA in PBS. Total fluorescence per sample was determined with a fluorescence microplate reader using the following band-pass filters: 488-nm excitation and 515-nm long-pass filter for detection of the fluorescein as previously described [28].

Hydrogen peroxide assay

Cellular $\mathrm{H}_{2} \mathrm{O}_{2}$ levels were determined using the Amplex Red Hydrogen Peroxide/Peroxidase Assay Kit (Molecular
Probes, Life Technologies; Carlsbad, CA, USA). GF-1 cells or $\mathrm{Cu} / \mathrm{Zn}$ SOD and CAT-expressing GF-1 cells described previously [23] $\left(10^{5} / \mathrm{mL}\right)$ were cultured to monolayer confluence in $60-\mathrm{mm}$ diameter culture dishes for $20 \mathrm{~h}$, rinsed twice with PBS, and transfected with one of three plasmids (pFlag, pFlag-B2, or pFlag-B2 $\Delta$ ) and then incubated at $28^{\circ} \mathrm{C}$ for 0,24 , or $48 \mathrm{~h}$. After the medium was removed, the cells were washed with PBS, lysed in $0.1 \mathrm{~mL}$ of lysis buffer $(50 \mathrm{mM}$ Tris $\mathrm{HCl}, \mathrm{pH} 7.4$, $150 \mathrm{mM} \mathrm{NaCl}, 1 \mathrm{~m}$ M EDTA, $1 \%$ Triton X-100, $0.5 \mathrm{mM}$ PMSF) with shaking at $4{ }^{\circ} \mathrm{C}$ for $30 \mathrm{~min}$. After centrifugation at $13,000 \mathrm{rpm}$ for $2 \mathrm{~min}$ at $4{ }^{\circ} \mathrm{C}$ to pellet the insoluble materials, $50 \mu \mathrm{L}$ of supernatant was mixed with $100 \mu \mathrm{M}$ Amplex Red and $0.2 \mathrm{U} / \mathrm{mL}$ horseradish peroxidase and incubated at room temperature for $30 \mathrm{~min}$ in the dark. Fluorescence was measured in a microplate reader with excitation at $570 \mathrm{~nm}$ and fluorescence emission detection at $585 \mathrm{~nm}$. Background fluorescence of the control (no $\mathrm{H}_{2} \mathrm{O}_{2}$ ) was subtracted from each reading.

Propidium iodide (PI) staining

Cells $\left(10^{5} / \mathrm{mL}\right)$ were cultured to monolayer confluence in 60-mm culture dishes for $20 \mathrm{~h}$, rinsed twice with PBS, then transfected with either pFlag or pFlag-B2 for $2 \mathrm{~h}$. Cells were then treated with either $1 \mathrm{mM}$ NAC or $5 \mu \mathrm{M}$ Mdivi (both Sigma) at $28{ }^{\circ} \mathrm{C}$ for 48 and $72 \mathrm{~h}$. After the medium was removed, the monolayers were washed with PBS, incubated with $100 \mu \mathrm{L}$ of PI (Boehringer-Mannheim Mannheim, Germany) in HEPES buffer for 10-15 min and evaluated using fluorescence microscopy as previously described [26].

Selection of zebrafish $\mathrm{Cu} / \mathrm{Zn}$ SOD and catalaseproducing GF-1 cells

Zebrafish $\mathrm{Cu} / \mathrm{Zn}$ SOD and catalase (zfCu/Zn SOD and zfCatalase, respectively) were cloned and inserted into the pBudCE4.1 expression vector (designated pBudCE4.1zfCu/Zn SOD or pBudCE4.1-zfCatalase, respectively) by Dr. Ken [23]. pBudCE4.1- (negative control) and pBudCE4.1-zfCatalase-expressing cells were obtained by transfection of GF- 1 cells and selection with Zeocin $(500 \mu \mathrm{g} /$ $\mathrm{mL}$ ). Transcription of the inserted sequences was driven by the immediate-early promoter of human cytomegalovirus in these vectors. Selection time (2-2.5 months) varied based on cell-line-dependent properties.

Flow cytometric analysis for cell viability

Viability analysis was conducting on the following cells: stained Flag and Flag-B2-transfected 293T cells, and a variety of cancer cell lines, including HeLa, MCF-7, A549, 
and H1299 cells (a p53-/- cell line). Analyses were performed using a FACS Vantage cell sorter (BectonDickinson, San Jose, CA, USA) to evaluate PI red fluorescence using a 650-nm long-pass bandpass filter. Altered cells have a higher PI fluorescence intensity $\left(\mathrm{PI}^{+}\right)$as compared to intact cells $\left(\mathrm{PI}^{-}\right)$. At least 10,000 cells in the gated region were analyzed on the basis of light scatter properties. Fluorescence data were displayed on one or two major scales as previously described [22].

\section{Preparation of mitochondria from B2-transfected cells}

GF-1 cells were seeded in $60-\mathrm{mm}$ diameter culture dishes with $3 \mathrm{~mL}$ of medium $\left(10^{5}\right.$ cells $\left./ \mathrm{mL}\right)$ for $20 \mathrm{~h}$. GF1 cells were treated with $1 \mathrm{mM} \mathrm{NAC}$ and $5 \mu \mathrm{M}$ Mdivi or were transfected with Flag, Flag-B2 $\Delta$ and Flag-B2 for $48 \mathrm{~h}$. At each change of the culture medium, $1 \mathrm{~mL}$ medium was removed. Mitochondria were isolated by modification of a previously described protocol [6]. Briefly, GF-1 cells $\left(2 \times 10^{6}\right)$ were washed with PBS and homogenized in $0.3 \mathrm{~mL}$ of mitochondria isolation buffer $(0.35 \mathrm{M}$ mannitol, $10 \mathrm{mM}$ HEPES, pH 7.2, $0.1 \%$ bovine serum albumin) using a glass homogenizer. Unbroken cells and nuclei were pelleted by centrifugation $\left(600 \times g\right.$ for $5 \mathrm{~min}$ at $\left.4{ }^{\circ} \mathrm{C}\right)$. The mitochondrial pellet was isolated by centrifugation $\left(10,000 \times g\right.$ for $10 \mathrm{~min}$ at $\left.4{ }^{\circ} \mathrm{C}\right)$; the supernatant was collected and mixed with $25 \mu \mathrm{L}$ of $10 \times$ SDS sample buffer. Samples $(50 \mu \mathrm{L})$ were boiled and subjected to Western blot analysis as previously described [25, 27].

Maintenance of fish embryos in culture

Techniques for the care and breeding of zebrafish have been previously described in detail [28]. Embryos were collected from natural mating and maintained in embryonic medium $\left(15 \mathrm{mM} \mathrm{NaCl}, 0.5 \mathrm{mM} \mathrm{KCl}, 1 \mathrm{mM} \mathrm{CaCl}_{2}, 1 \mathrm{mM}\right.$ $\mathrm{MgSO}_{4}, \quad 0.05 \mathrm{mM} \quad \mathrm{Na}_{2} \mathrm{HPO}_{4}, \quad 0.7 \mathrm{mM} \quad \mathrm{NaHCO}_{3}$ ) at $28.5^{\circ} \mathrm{C}$. Embryos were staged according to standard morphological criteria [28].

\section{Microinjection of EYFP and EYFP-B2}

To induce expression of the $\mathrm{B} 2$ protein in zebrafish embryos, $2 \mu \mathrm{L}$ of a $10 \mathrm{ng} / \mu \mathrm{L}$ pEYFP-C1/pEYFP-B2 solution (linearized with EcoRI) was injected into each one-cell-stage embryo using a gas-driven microinjector (Medical System Corporation, Greenvale, NY, USA) as previously described [28].

\section{MitoTracker}

To track changes in mitochondrial morphology, cells were transfected with pEYFP and pEYFP-B2 using
Fig. 1 RGNNV B2 protein is targeted to the mitochondria and induces $\mathrm{H}_{2} \mathrm{O}_{2}$ production in fish cells. A Schematic representation of various full-length and mutant RGNNV B2 protein constructs used to identify the mitochondrial targeting sequence. B Immunoblot using monoclonal antibodies against the Flag tag shows the expression of various forms of Flag-B2. The internal control, actin, was shown at 48 $\mathrm{h}$ post-transfection. C Immunoblot using monoclonal antibodies against the Flag tag shows the protein distribution in either mitochondrial or cytosolic extracts at $48 \mathrm{~h}$ post-transfection. The internal controls included actin for the cytosolic fraction and VDAC for mitochondria membrane fraction. D GF-1 cells were transfected with EYFP, EYFP-B2 and EYFP-B2 $\Delta$, and their protein distribution was determined at $48 \mathrm{~h}$ post-transfection. EYFP-B2 protein was localized to mitochondria (D(b); indicated by arrows). GF-1 cells, transfected with EYFP-B2 (D(d); green fluorescence), were also stained with mitotracker at $48 \mathrm{~h}$ post-transfection $(\mathbf{D}(\mathrm{e})$; red staining); the merged image from $\mathbf{D}(\mathrm{d})$ and $\mathbf{D}(\mathrm{e})$ showed mitochondrial fragmentation indicated by arrows (D(f)). Scale bar $10 \mu \mathrm{m}$. E ROS production (green indicated by arrows) at $72 \mathrm{~h}$ post-transfection by cells transfected with RGNNV B2 (b and e). The negative control was Flag alone (a and d) and Flag-B2 (del ${ }^{41}$ RTFVISAHAA ${ }^{50}$ ) (c and f). Scale bar $10 \mu \mathrm{m}$. F The percentage of ROS-producing cells at 48 and $72 \mathrm{~h}$ post-transfection. Error bars represent the SEM of three independent experiments. All data were analyzed using either a paired or unpaired Student's $t$ test, as appropriate. ${ }^{*} P<0.01$. G Concentration of $\mathrm{H}_{2} \mathrm{O}_{2}$ in medium from EYFP-, EYFP-B2-, and EYFP-B2 $\Delta$-transfected cells at $72 \mathrm{~h}$ post-transfection. $\mathrm{H}_{2} \mathrm{O}_{2}$ concentration at each time point was determined in triplicate. All data were analyzed using either a paired or unpaired Student's $t$ test, as appropriate. $* P<0.01$

Lipofectamine-Plus (Life Technologies) according to the manufacturer's instructions and treated with $1 \mathrm{mM}$ NAC and $10 \mu \mathrm{M}$ Mdivi. Cells were then stained with MitoTracker Red $\mathrm{CM}-\mathrm{H}_{2} \mathrm{XRos}$ (Invitrogen). Live cells were labeled with the mitochondrion-specific dye in accordance with the manufacturer's instructions, after which cells were analyzed by fluorescence microscopy using $488 \mathrm{~nm}$ excitation and a $515 \mathrm{~nm}$ long-pass filter for green fluorescence and using $510 \mathrm{~nm}$ excitation and a $590 \mathrm{~nm}$ long-pass filter for red fluorescence previously described [21, 22].

Immunostaining of Drp1 distribution in intact cells

GF-1 cells were seeded in 6-well plates with $2.5 \mathrm{~mL}$ of medium $\left(10^{5}\right.$ cells $\left./ \mathrm{mL}\right)$ for $20 \mathrm{~h}$ and then transfected with EYFP, EYFP-B2 and EYFP-B2 $\Delta$ for $48 \mathrm{~h}$. The cells were washed with cold PBS, fixed in $4 \%$ formaldehyde for $30 \mathrm{~min}$ at room temperature, washed with PBS twice and then permeabilized with PBST buffer $(0.1 \%$ Triton X-100 in PBS) for $15 \mathrm{~min}$ at room temperature. After the cells were washed with PBS twice, they were blocked with $1 \%$ BSA for 60 min at RT, and then incubated overnight at $4{ }^{\circ} \mathrm{C}$ with antibodies against Drp1 (1:50, Aviva Systems Biology, San Diego, CA, USA) overnight. After cells were washed with PBST buffer twice, they were incubated for 60 min with Alexa Fluor ${ }^{\circledR} 405$ Goat Anti-Rabbit IgG $(\mathrm{H}+\mathrm{L})(1: 500$, Invitrogen) in $1 \%$ BSA and washed with 
A

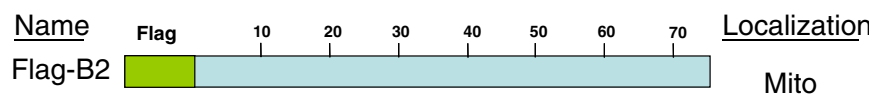

Flag-B2 $\triangle \quad \square_{40}-\square_{51} \quad$ Diffuse Flag

B

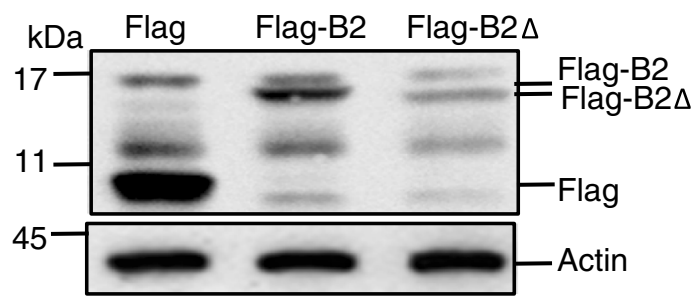

E

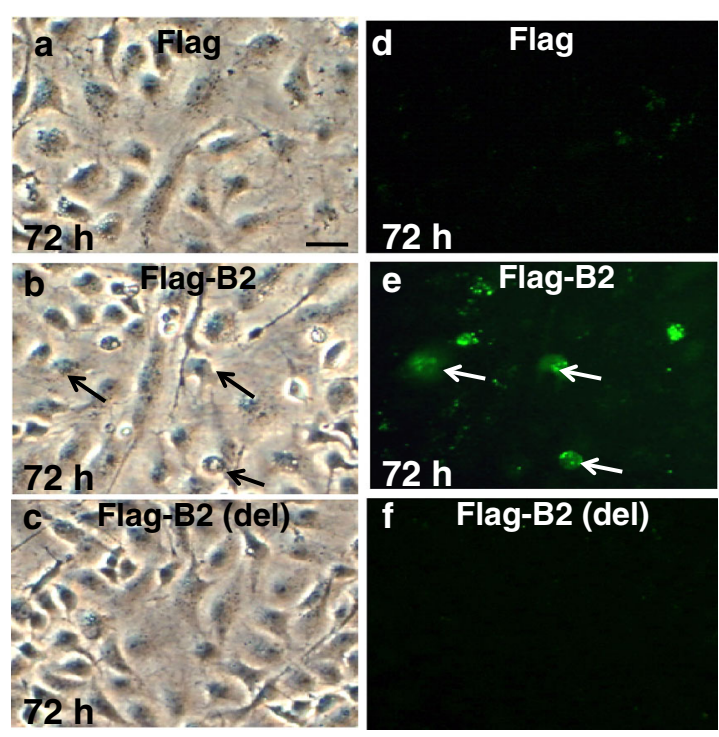

G

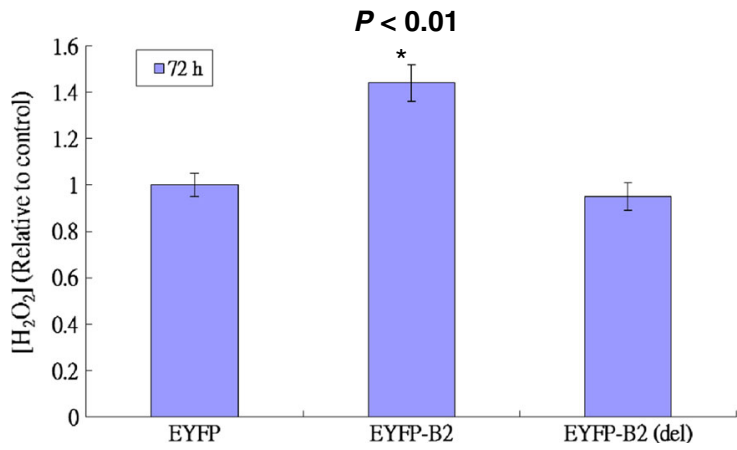

PBST twice. Immunofluorescence was examined using an Olympus IX70 fluorescence microscope (Tokyo, Japan) at 488-nm excitation and 515-nm long-pass filter for detection EYFP-B2 protein (with green fluorescence); 330-nm excitation and 420-nm long-pass filter was used for detection of the blue florescence (with Drp1) in the mitochondria.
C
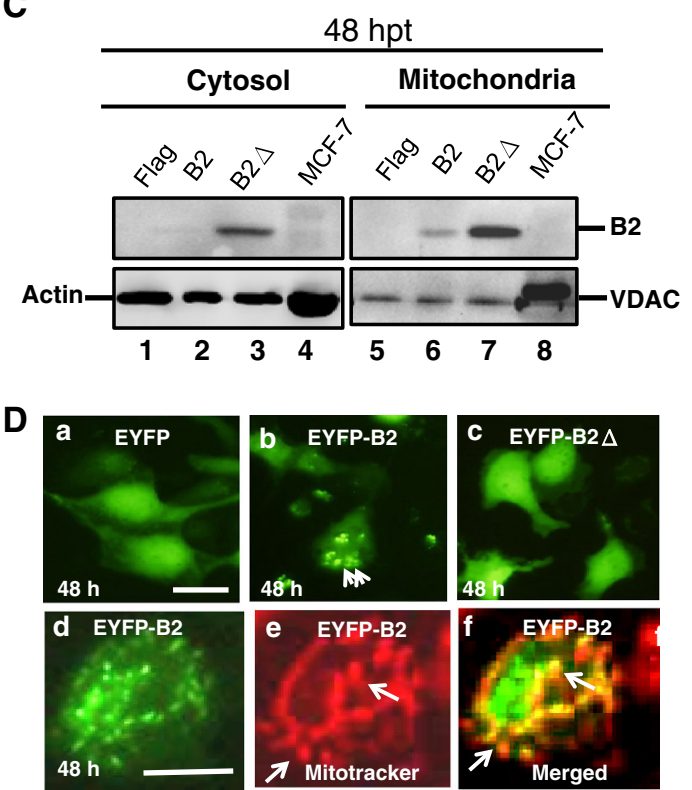

$\mathbf{F}$

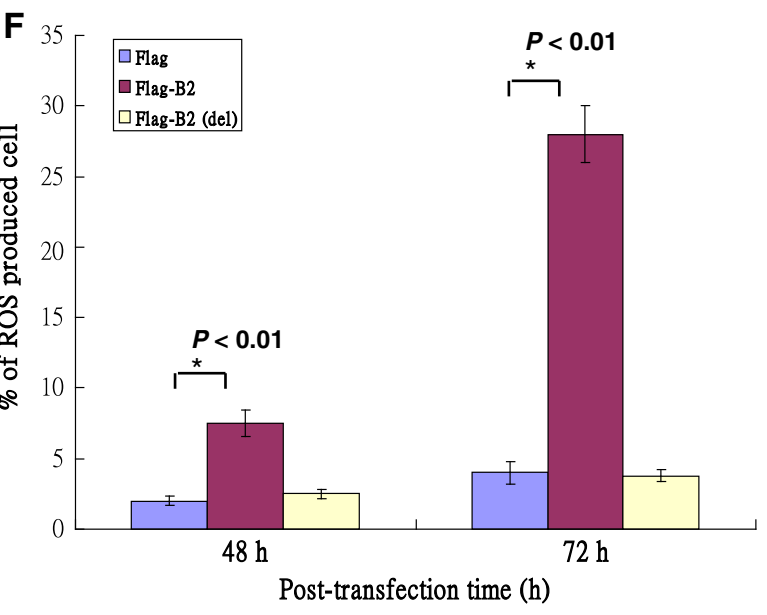

Quantification of cell viability

GF-1 cells expressing pBudCE4.1 (control), zfMn SOD-2, and zfCatalase-3 (all $10^{5}$ cells $/ \mathrm{mL}$ ) were cultured in 60 -mm diameter culture dishes at $28^{\circ} \mathrm{C}$. After $0,24,48$, or $72 \mathrm{~h}$, cells were washed with PBS and treated with $0.5 \mathrm{~mL}$ of $0.1 \%$ trypsin-EDTA (Gibco, Grand Island, NY, USA) 
for 1-2 min. Cell viability was determined in triplicate using the trypan blue dye exclusion assay as previously described [29]. Each data point (10,000 cells) represents the mean viability of three independent experiments \pm SEM.

\section{Statistical analysis}

The proportion of ROS production and PI-fluoresceinpositive cells was determined in each sample by counting 200 cells. Each result is expressed as the mean \pm SEM. Data were analyzed using either paired or unpaired Student's $t$ tests, as appropriate. A $P$ value $<0.05$ was considered a statistically significant difference between group mean values.

\section{Results}

Mitochondrial targeting of $\mathrm{B} 2$ protein is required for induction of free-radical species $-\mathrm{H}_{2} \mathrm{O}_{2}$ production

The betanodavirus B2 protein has a specific signal peptide that targets it to mitochondria [22]. To determine whether mitochondrial targeting of the B2 protein is required for B2mediated cell death, we constructed a $B 2$ gene with an $\mathrm{N}$-terminal deletion that eliminates the signal sequence (del ${ }_{40-51}$; termed Flag-B2 $\Delta$ ) and fused it to a Flag tag (Fig. 1A). Recombinant plasmids were transfected into GF1 cells and detected in whole cell lysates (Fig. 1B) as well as cytosolic or mitochondrial fractions (Fig. 1C) by Western blot analysis. Most B2 was localized to mitochondria (Fig. 1C, lane 6) as compared to the cytosol (Fig. 1C, lane 2 ). However, the $\mathrm{B} 2 \Delta$ protein was localized to both the cytosol and mitochondria (Fig. 1C, lanes 3 and 7, respectively), suggesting that it may be anchored to the outer mitochondrial membrane through a yet unknown domain or structure. Separate immunofluorescence analysis confirmed that EYFP-B2 was primarily targeted to the mitochondria (Fig. 1D(b); indicated by arrows) as compared with EYFP alone (Fig. 1D(a)); EYFP-B2 $\Delta$ was distributed throughout the cells (Fig. 1D(c)). EYFP-B2 targeting to mitochondria was confirmed using the mitochondria-specific dye, Mitotracker red (Fig. 1D(d-f); indicated by arrows).

In a ROS production assay, Flag-B2 expression induced ROS production as indicated by a punctate pattern and lethal morphological changes in cells producing ROS at $72 \mathrm{~h}$ posttransfection (Fig. 1E(b, e); indicated by arrows). However, cells expressing the Flag-B2 $\Delta$ protein with the N-terminal deletion also showed a mild punctate pattern and the same morphology (Fig. 1E(c, f)) compared to those expressing Flag (Fig. 1E(a, d)). As shown in Fig. 1F, expression of the full-length B2 protein induced a 4.5 and $24 \%$ increase in
ROS production at 48 and $72 \mathrm{~h}$ post-transfection, respectively, when compared with vector alone ( 2 and $3.9 \%$ at 48 and $72 \mathrm{~h}$ post-transfection, respectively) and the $\mathrm{B} 2 \Delta$ mutant ( 3 and $3.8 \%$ at 48 and $72 \mathrm{~h}$ post-transfection, respectively). Furthermore, as shown in Fig. 1G, expression of the fulllength $\mathrm{B} 2$ protein induced $\mathrm{H}_{2} \mathrm{O}_{2}$ production by up to 1.48fold as compared to either vector alone (baseline, 1 -fold) or the B2 $\Delta$ mutant $(0.95$-fold $)$ at $72 \mathrm{~h}$ post-transfection. Taken together, these data indicate that residues $41-50$ of the B2 protein target the protein to the mitochondria, where it plays a role in $\mathrm{H}_{2} \mathrm{O}_{2}$ production.

\section{B2 can trigger $\mathrm{H}_{2} \mathrm{O}_{2}$-mediated cancer cell death}

To elucidate the mechanism by which $\mathrm{B} 2$ protein induces cell death through ROS production, we measured intracellular $\mathrm{H}_{2} \mathrm{O}_{2}$ levels in human 293T cells and in HeLa, MCF-7 A549, and H1299 cancer cell lines (Fig. 2A). At $36 \mathrm{~h}$ post-transfection, overexpression of the full-length $\mathrm{B} 2$ protein significantly increased intracellular $\mathrm{H}_{2} \mathrm{O}_{2}$ levels in $293 \mathrm{~T}$ cells (2.1-fold), HeLa cells (1.5-fold), MCF-7 cells (1.2-fold), A549 cells (1.4-fold), and H1299 cells (1.7-fold) compared to cells expressing vector alone (all $P<0.01$ ). Cell viability analysis, as determined by PI staining assay, showed that full-length B2 protein can induce cell death in up to $33 \%$ of 293 T cells, $25 \%$ of HeLa cells, $11 \%$ of MCF-7 cells, $34 \%$ of A549 cells and $59 \%$ of H1299 cells relative to cells expressing the vector alone at $72 \mathrm{~h}$ posttransfection (Fig. 2B), which suggested that cell death was induced via $\mathrm{H}_{2} \mathrm{O}_{2}$ production.

$\mathrm{N}$-acetylcysteine (NAC) suppresses B2-induced cell death in fish cells by inhibiting $\mathrm{H}_{2} \mathrm{O}_{2}$ production

To determine whether inhibiting $\mathrm{H}_{2} \mathrm{O}_{2}$ production can rescue cells from EYFP-B2-induced death, we assessed cell death in the presence of the anti-oxidant, NAC. As shown in Fig. 3A, EYFP-B2-expressing cells induced up to a 1.5-fold increase in $\mathrm{H}_{2} \mathrm{O}_{2}$ production over cells expressing EYFP alone $(P<0.01)$, which was inhibited in the presence of NAC ( 0.8 -fold) at $72 \mathrm{~h}$ post-transfection. Treatment of EYFP-B2-expressing cells with NAC increased cell survival to levels observed in cells expressing EYFP alone at both 48 and $72 \mathrm{~h}$ post-transfection (Fig. 3B), which was significantly greater than that observed in EYFP-B2-expressing cells $(P<0.01)$.

Overexpression of SOD and catalase can reduce B2induced cell death in fish cells by suppressing $\mathrm{H}_{2} \mathrm{O}_{2}$ production

To determine whether anti-oxidant enzymes can block $\mathrm{H}_{2} \mathrm{O}_{2}$ production and affect host cell viability, zebrafish 
Fig. 2 B2 protein induces $\mathrm{H}_{2} \mathrm{O}_{2}$ production and cell death in cancer cell lines. A The ratios of $\mathrm{H}_{2} \mathrm{O}_{2}$-producing cells were counted using a fluorescence microplate reader at $36 \mathrm{~h}$. Error bars represent the SEM. All data were analyzed using either a paired or unpaired Student's $t$ test, as appropriate. $* P<0.01$. B Representative flow cytometric profiles at $36 \mathrm{~h}$ posttransfection. PI staining fluorescence was measured from 10,000 cells. Numbers in subpopulation cells $\left(\mathrm{PI}^{+}\right)$show late apoptotic secondary necrotic cell percentages. The percentage of viable cells $\left(\mathrm{PI}^{+}\right)$ in the major and sub-major population was shown. The $\mathrm{Y}$-axes indicate the cell numbers
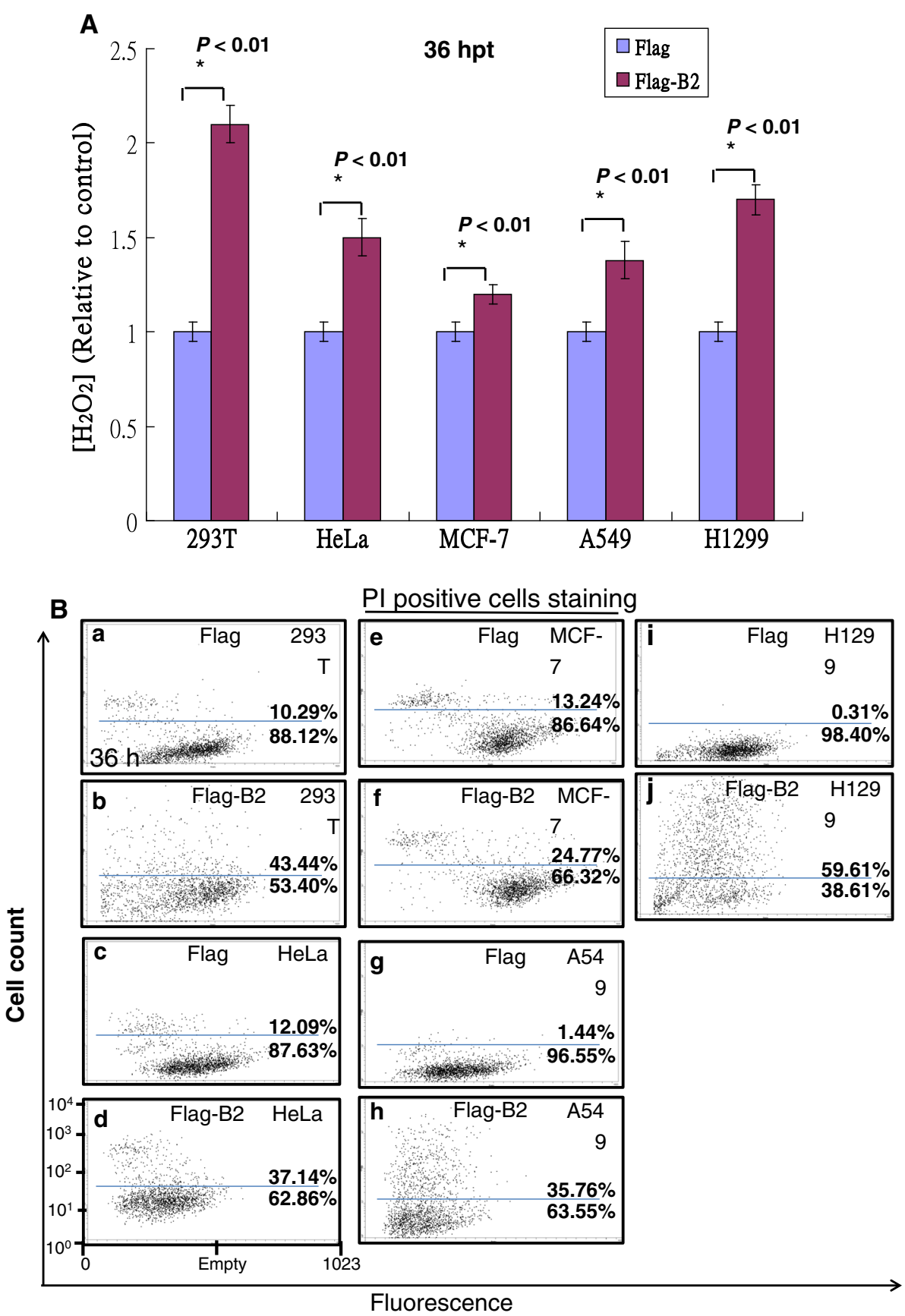

cells overexpressing $\mathrm{Cu} / \mathrm{Zn}$ SOD and catalase were selected; the transfection efficiency was approximately $40 \%$. As shown in Fig 4A, cells overexpressing full-length $\mathrm{B} 2$ protein had 1.8-fold increased $\mathrm{H}_{2} \mathrm{O}_{2}$ production; $\mathrm{H}_{2} \mathrm{O}_{2}$ production in cells expressing zfCu/Zn SOD and zfCatalase was 0.8 - and 0.7 -fold that observed for cells expressing vector alone at $72 \mathrm{~h}$ post-transfection, respectively. Furthermore, the viability of cells expressing full-length B2 was increased by approximately 5, 12 and $14 \%$ with zfCu/ Zn SOD expression and 6, 14 and $18 \%$ with zfCatalase expression at 24,48 , and $72 \mathrm{~h}$ post-transfection, respectively $(P<0.01$; Fig. 4B). These results are consistent with those shown in Figs. 3 and 4A, demonstrating that $\mathrm{H}_{2} \mathrm{O}_{2}$ stress damage induced by $\mathrm{B} 2$ protein could be rescued by either NAC or the antioxidant enzymes, zfCu/Zn SOD and zfCatalase.

B2 protein expression induces $\mathrm{H}_{2} \mathrm{O}_{2}$ production and upregulation of anti-oxidant enzymes and $\mathrm{Nrf} 2$ via oxidative stress in early zebrafish embryos

To establish whether $\mathrm{B} 2$ protein is directly responsible for $\mathrm{H}_{2} \mathrm{O}_{2}$-dependent cell death in vivo, the effect of $\mathrm{B} 2$ protein expression in zebrafish embryos was examined. Because 

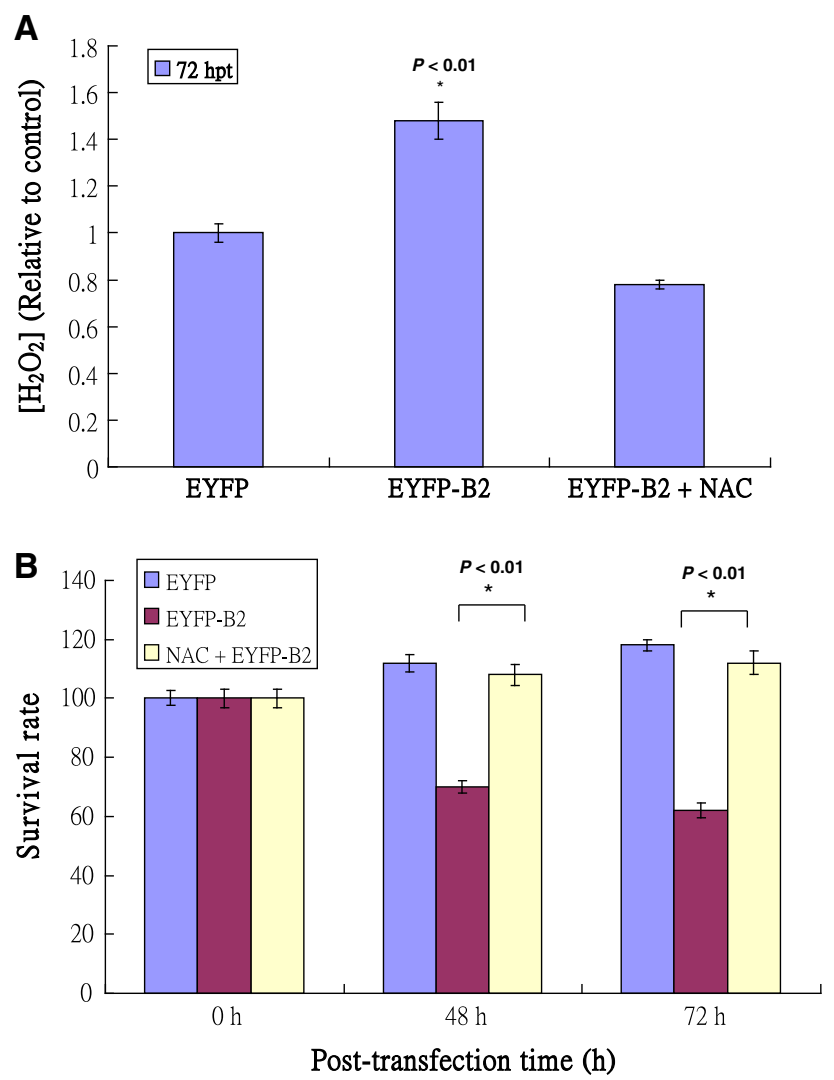

Fig. 3 Effect of $\mathrm{NAC}$ treatment on $\mathrm{H}_{2} \mathrm{O}_{2}$ production in fish cell expressing B2 protein. A Concentration of $\mathrm{H}_{2} \mathrm{O}_{2}$ in the medium of EYFP-, EYFP-B2-, and EYFP-B2 + NAC-transfected cells at $72 \mathrm{~h}$ post-transfection. $\mathrm{H}_{2} \mathrm{O}_{2}$ concentration at each time point was determined in triplicate. B Survival rate assays in the EYFP-, EYFP-B2-, and EYFP-B2 + NAC-transfected cells at 0, 48, and $72 \mathrm{~h}$ posttransfection. Survival rate was determined in triplicate using the trypan blue dye exclusion assay [29]. Each data point (10,000 cells) represents the mean viability of three independent experiments \pm SEM. Data were analyzed using either a paired or unpaired Student's $t$ test, as appropriate $* P<0.01$

embryos injected with high doses (30 ng/ $\mu \mathrm{L})$ of pEYFP-B2 did not survive $10 \mathrm{~h}$ post-fertilization (hpf), lower doses $(10 \mathrm{ng} / \mu \mathrm{L})$ were employed. The EYFP-B2 fusion protein caused abnormal development at $10 \mathrm{hpf}(\mathrm{Fig} .5 \mathrm{~A}(\mathrm{e}, \mathrm{f}))$ that was lethal at $24 \mathrm{hpf}(\mathrm{Fig} .5 \mathrm{~A}(\mathrm{~g}, \mathrm{~h})$ ) via cell death. Compared with EYFP-injected embryos (Fig. 5A(b, d)), EYFPB2-injected embryos showed apoptotic cell accumulation (Fig. 5A(f, h)).

ROS production in injected embryos was next determined. EYFP-B2 fusion protein expression caused rapid increases in intracellular $\mathrm{H}_{2} \mathrm{O}_{2}$ levels of approximately 1.3fold (at $10 \mathrm{hpf}$ ) and 1.78-fold (at $24 \mathrm{hpf}$ ) as compared to vector alone (Fig. 5B). Furthermore, qRT-PCR analysis indicated that $\mathrm{B} 2$-induced oxidative stress upregulated Nrf2 (2.3-fold), Cu/Zn SOD (2.9-fold), Mn SOD (2.2-fold) and catalase (1.7-fold) expression at $10 \mathrm{hpf}$ (Fig. 5C). However, at $24 \mathrm{hpf}$, only catalase (1.9-fold) was
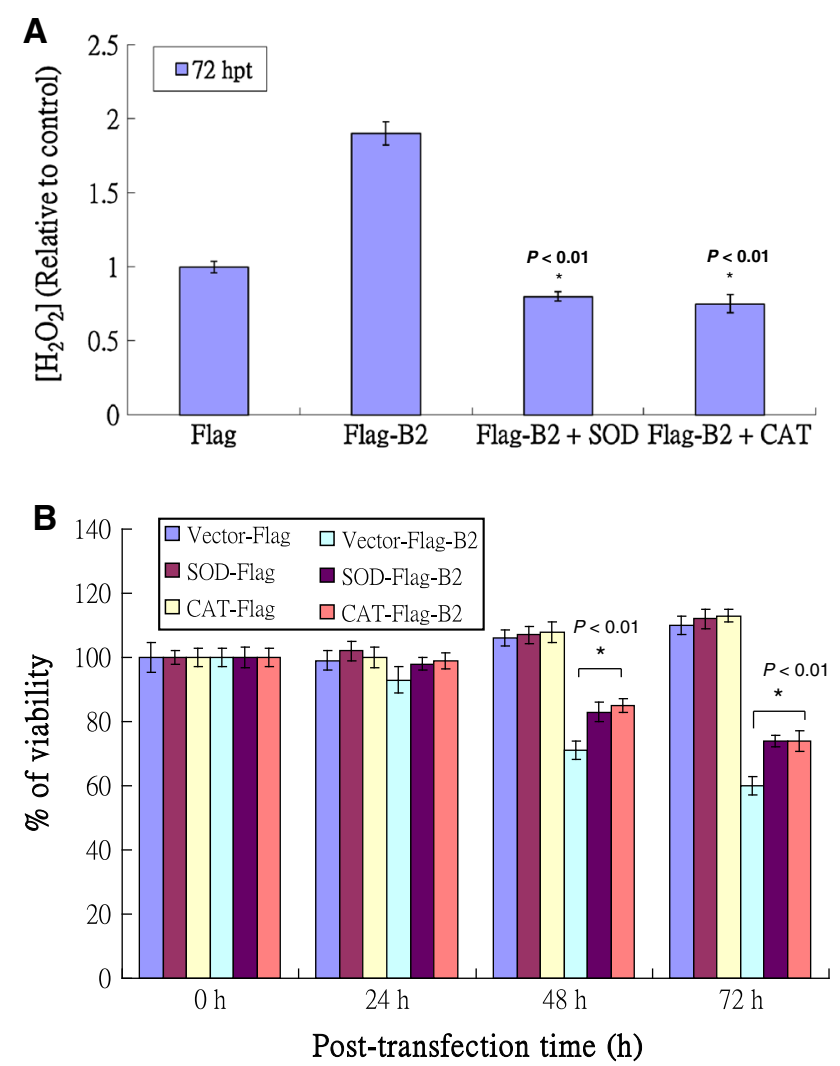

Fig. 4 Overexpression of zebrafish $\mathrm{Cu} / \mathrm{Zn}$ SOD and catalase reduced B2-induced cell death in GF-1 cells by suppressing $\mathrm{H}_{2} \mathrm{O}_{2}$ production. A $\mathrm{H}_{2} \mathrm{O}_{2}$ production by $\mathrm{GF}-1$, zebrafish $\mathrm{Cu} / \mathrm{Zn}$ SOD and catalaseproducing cell lines transfected with Flag or Flag-B2 at $72 \mathrm{~h}$ posttransfection as determined using a fluorescence microplate reader. Error bars represent the SEM. B Cell viability of vector control, zfSOD- and zfCatalase-transduced GF-1cells transfected with or without Flag-B2 at 0, 24, 48 and $72 \mathrm{~h}$ post-transfection in triplicate using a trypan blue dye exclusion assay. The data were analyzed using either a paired or unpaired Student's $t$ test, as appropriate. $* P<0.01$

upregulated as compared to the vector-only control (Fig. 5C). These results suggest that $\mathrm{B} 2$ protein expression caused cell death in vivo by increasing $\mathrm{H}_{2} \mathrm{O}_{2}$ production, thus triggering oxidative stress.

B2 induced-mitochondria fragmentation is correlated with Drp1 recruitment into mitochondria (DRMC)

Changes in mitochondrial morphology in EYFP- B2transfected cells were monitored using fluorescence microscopy. B2 protein was localized in the mitochondria and induced mitochondrial fragmentation in cells at $48 \mathrm{~h}$ (Fig. 6A(d-f)). Mitochondrial fragmentation was reduced with NAC (Fig. 6A(g-i)) or Mdivi (Fig. 6A(j-1)), indicating that $\mathrm{H}_{2} \mathrm{O}_{2}$ signaling can affect mitochondrial morphology. As shown in Fig. $6 \mathrm{~B}$, the proportion of fragmented mitochondria was reduced by 19 and $18 \%$ with NAC and Mdivi treatment, respectively as compared 
Fig. 5 B2 protein induces $\mathrm{H}_{2} \mathrm{O}_{2}$ production, oxidative stress, and zebrafish embryonic death.

Embryos were injected with vector control (EYFP) or the $B 2$ gene (EYFP-B2) at the one-cell stage. A Phase-contrast images of the EYFP $(a, c)$ and the EYFP-B2 (10 ng/ $\mu \mathrm{L})$ group (e, g) stained with acridine orange at $10(\mathrm{~b}, \mathrm{f})$ and $24 \mathrm{~h}$ post-

fertilization $(\mathrm{d}, \mathrm{h})$.

B Intracellular $\mathrm{H}_{2} \mathrm{O}_{2}$ concentrations (fold-increase over vector control) of zebrafish embryos at 10 and $24 \mathrm{~h}$ postfertilization in triplicate. The data were analyzed using either a paired or unpaired Student's $t$ test, as appropriate. ${ }^{*} P<0.01$. C Up-regulation of $\mathrm{Nrf} 2, \mathrm{Cu}-\mathrm{Zn}$ SOD, Mn SOD, and catalase using qRT-PCR after EYFP and EYFP-B2 transfection at 10 and $24 \mathrm{~h}$ post-transfection
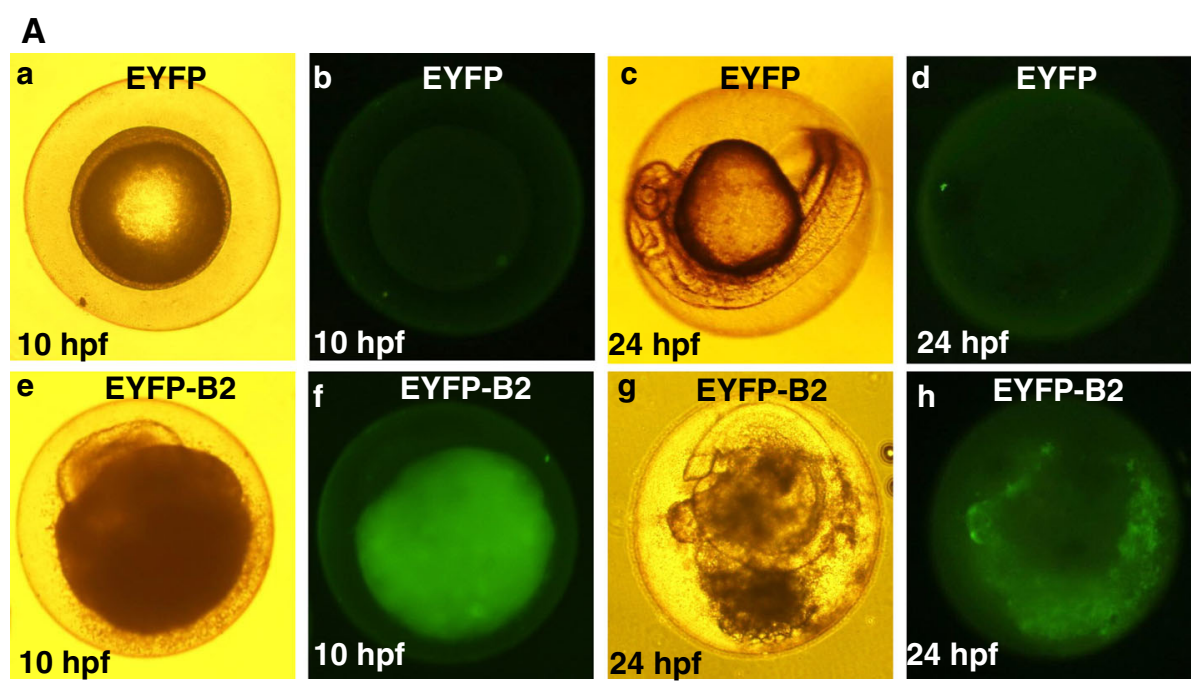

B

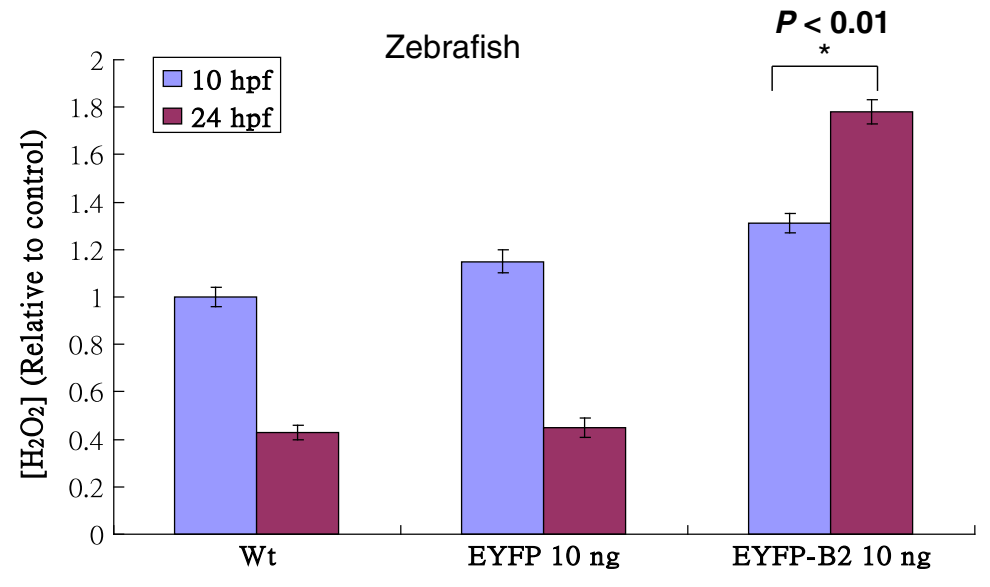

C

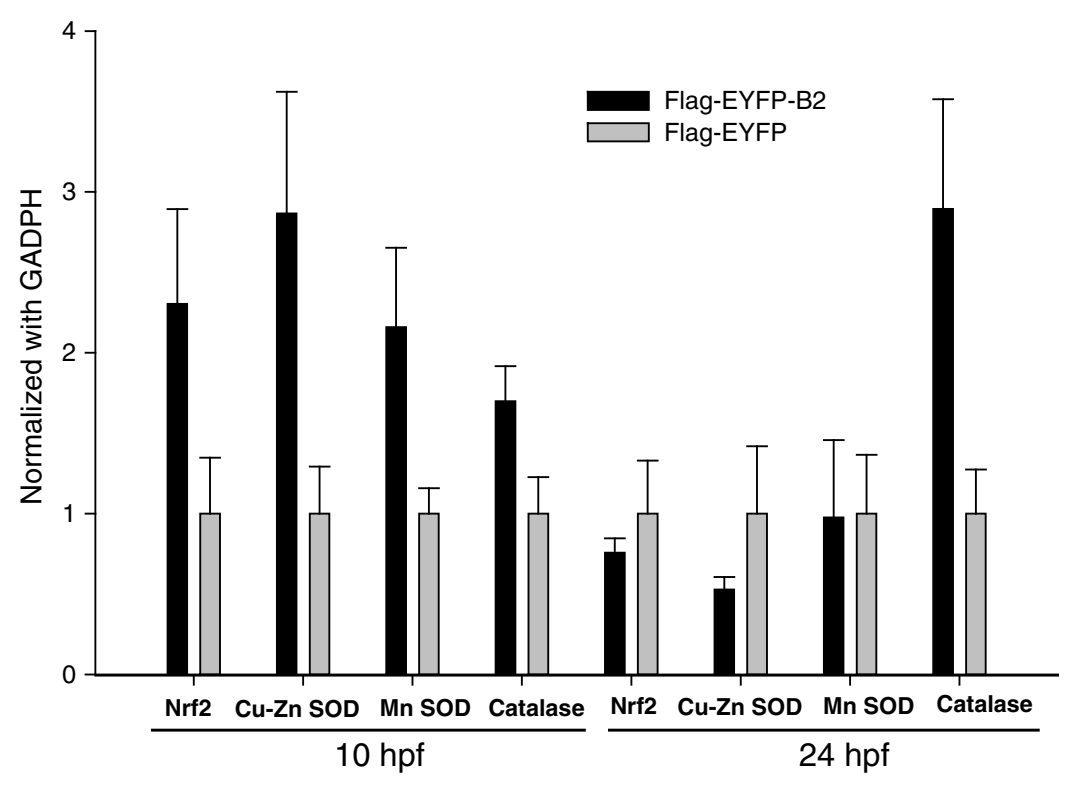



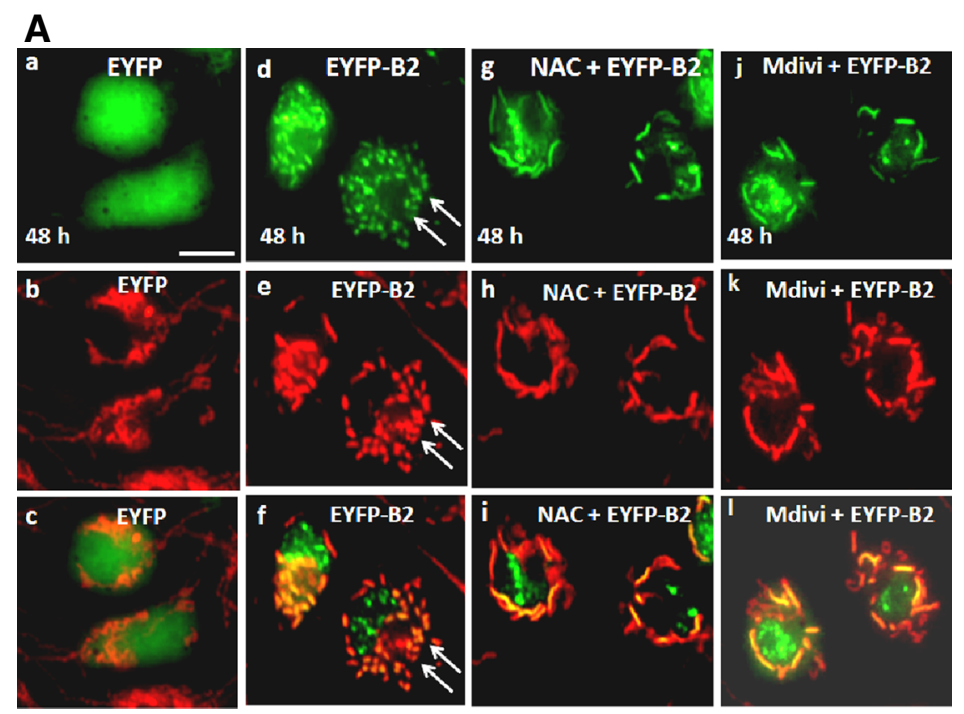

D

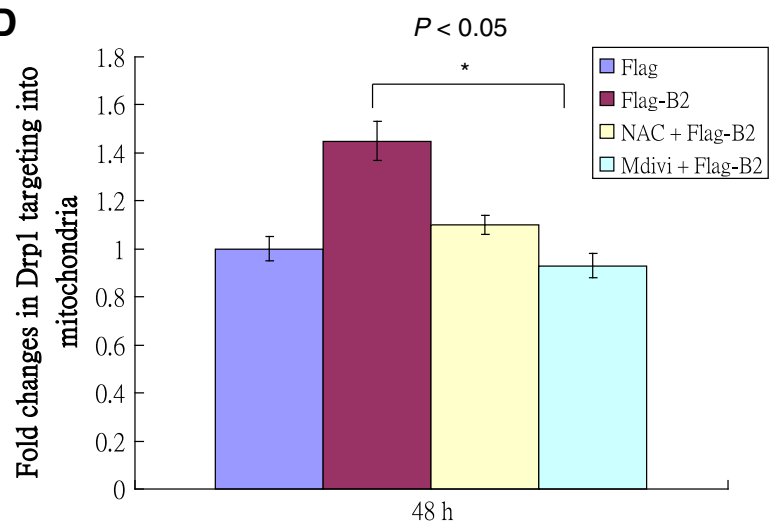

Post-transfection time $(\mathrm{h})$

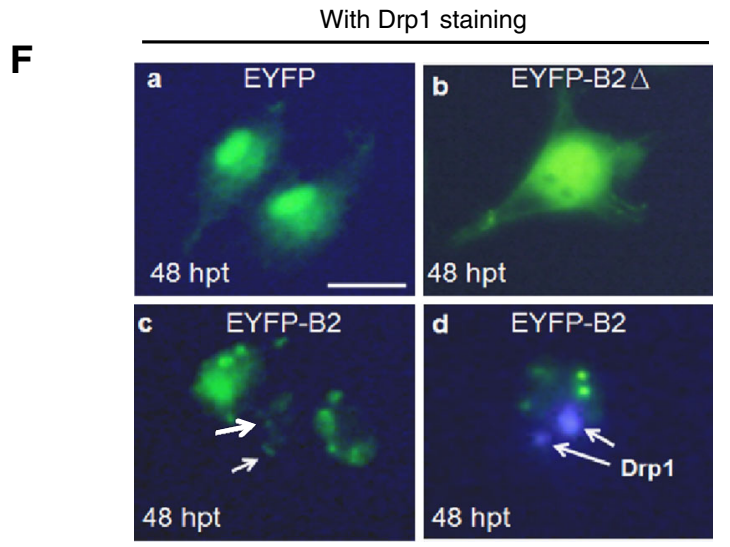

\section{B}

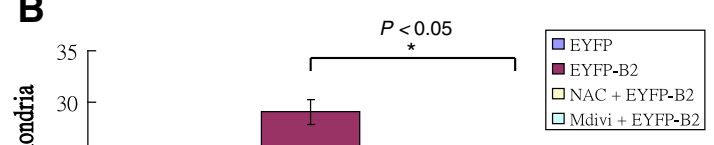

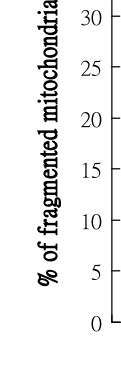

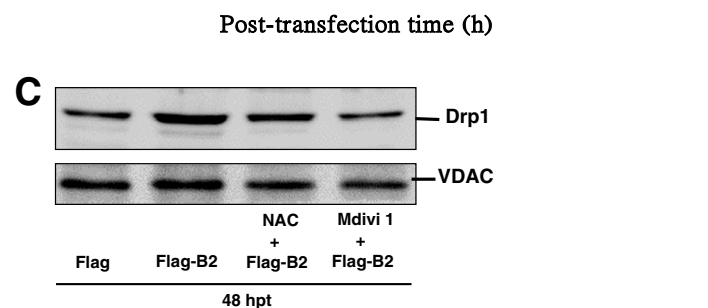

E

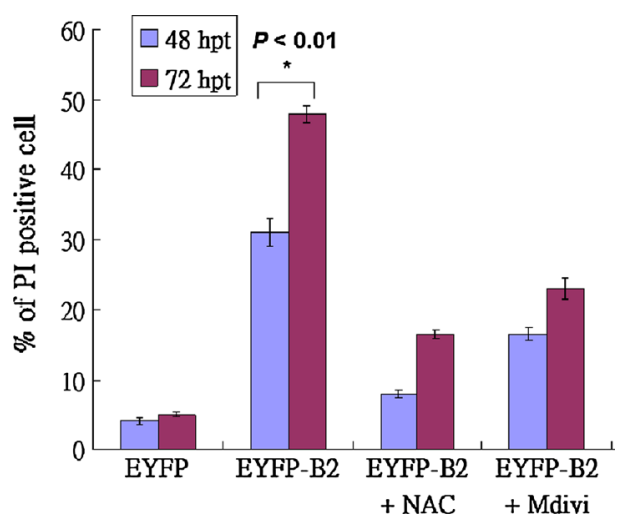

with untreated EYFP-B2-expressing cells (29\%; $P<0.05)$.

Western blot analysis also revealed that localization of full-length B2 to mitochondria results in the recruitment of Drp1 into the mitochondria (Fig. 6C), which was blocked by treatment with NAC (Fig. 6C, lane 3) and Mdivi (Fig. 6C, lane 4) as compared to the untreated group (Fig. 6C, lane 2) and negative control group (Fig. 6C, lane 1). Specifically, Drp1 recruitment to mitochondria was reduced by 0.35 - and 0.52 -fold with NAC and Mdivi 
4Fig. 6 Influence of RGNNV B2-induced $\mathrm{H}_{2} \mathrm{O}_{2}$ production on mitochondrial morphology and cell death in GF-1 cells. GF-1 cells were transfected with EYFP or EYFP-B2 and treated with and without NAC or Mdivi for $48 \mathrm{~h}$ and $72 \mathrm{~h}$. A Intracellular mitochondrial fragmentation (scale bar $10 \mu \mathrm{m}$ ) was determined by fluorescence microscopy, and $\mathbf{B}$ the induced fragmented mitochondrial ratio was determined in triplicate by individual analysis from A. C Drp1 translocation to mitochondria was blocked by either NAC or Mdivi treatment as determined by Western blot analysis of mitochondrial fractions. D Drp1 mitochondrial targeting from $\mathbf{C}$ was quantified by densitometry (Molecular Dynamic). E Cell viability was determined using the PI assay. F Co-localization analysis of protein B2 with Drp1 protein at $48 \mathrm{~h}$ post-transfection was detected in approximately 4-5\% cells with weak blue fluorescence $(\mathbf{F}(\mathrm{c})$; indicated by arrows) and with stronger blue fluorescence $(\mathbf{F}(\mathrm{d})$; indicated by arrows), which means at different cellular stages compared with EYFP- $(\mathbf{F}(a)$, staining of Drp1 alone) and EYFP-B2 $\Delta-(\mathbf{F}(\mathrm{b})$, with Drp1 staining) transfected cells. All data were analyzed using either paired or unpaired Student's $t$ tests as appropriate. $* P<0.01$

treatment, respectively relative to the Flag-B2 group $(P<0.05$; Fig. 6D).

Analysis of cell viability with PI staining indicated that cell death was decreased by 23 and $14 \%$ with NAC and Mdivi treatments, respectively compared to those without inhibitors at $48 \mathrm{~h}$ (Fig. 6E). After $72 \mathrm{~h}$, cell death was further decreased by 31 and $24 \%$ with NAC and Mdivi treatments, respectively (Fig. 6E), which correlated to Drp1 recruitment to mitochondria.

To determine if $\mathrm{B} 2$ protein and Drp1 co-localized in mitochondria, immunofluorescence analysis was undertaken.
At $48 \mathrm{~h}$ post-transfection, approximately $4-5 \%$ of the cells were strongly damaged (Fig. 6F(c,d); indicated by arrows). In these damaged cells, EYFP-B2 (green) and Drp1 (blue) were co-localized (6F: d) when compared with Drp1 staining in either EYFP- or EYFP-B2 $\Delta$-expressing cells (Fig. 6F(a,b)), which did not shown any blue image as a normal controls.

\section{Discussion}

The present study demonstrates that the viral B2 protein induces $\mathrm{H}_{2} \mathrm{O}_{2}$-mediated cell death through pathways that may involve the host anti-oxidant enzyme system and Drp1-mediated mitochondrial fragmentation. The RGNNV B2 protein induced $\mathrm{H}_{2} \mathrm{O}_{2}$ production in fish cells, human cancer cells, and embryonic zebrafish in a similar fashion in vitro and in vivo. The p53-null lung cancer cells (H1299) were more severely damaged than those expressing p53 (A549), resulting in a 0.3-fold increase in $\mathrm{H}_{2} \mathrm{O}_{2}$ production and a $25 \%$ increase in cell death. Furthermore, NAC dramatically reduced $\mathrm{H}_{2} \mathrm{O}_{2}$ production by 0.7-fold, and overexpression of $\mathrm{zfCu} / \mathrm{Zn}$ SOD and zfcatalase decreased $\mathrm{H}_{2} \mathrm{O}_{2}$ levels by 0.6 - and 1.0-fold, respectively, which coincided with increased cell viability at $72 \mathrm{~h}$ post-transfection. These results indicate that antioxidants and antioxidant enzymes may have therapeutic potential for preventing B2-protein-induced cell damaged.

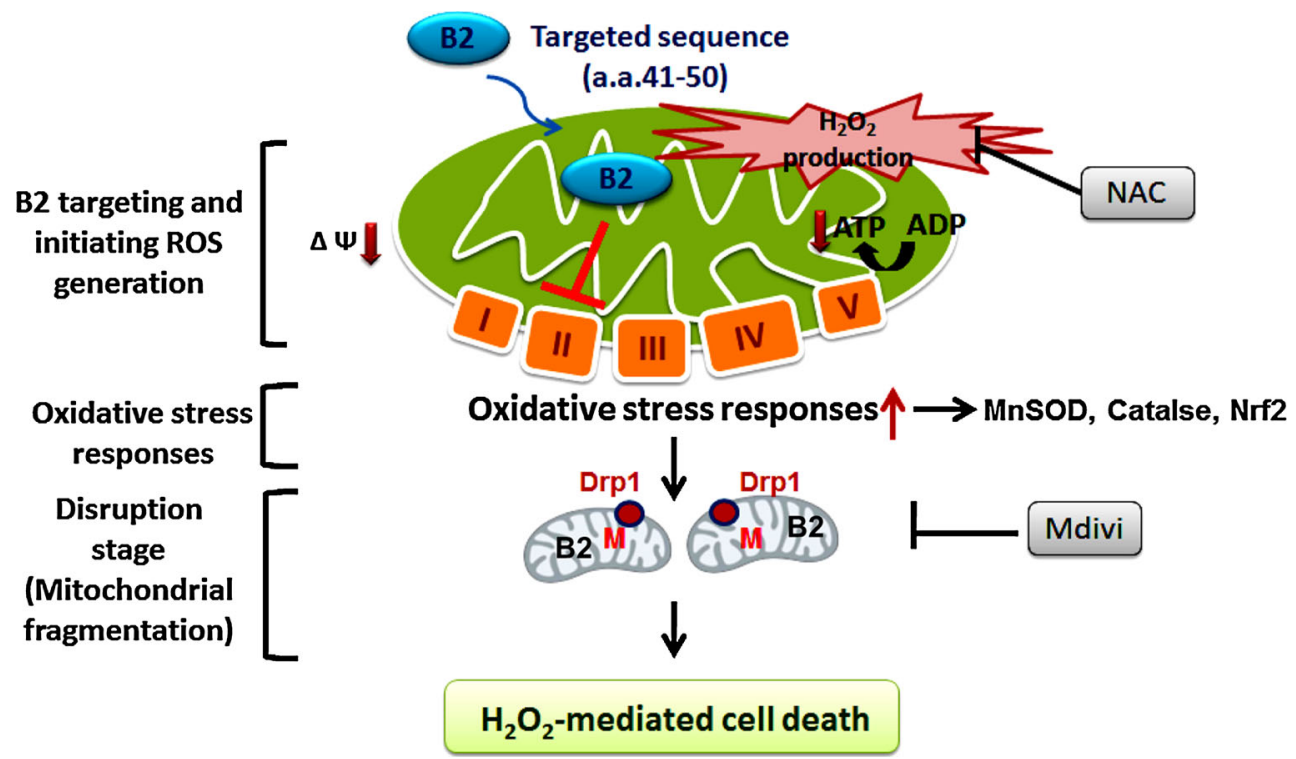

Fig. 7 Schematic illustration of a proposed mechanism by which protein $\mathrm{B} 2$ induces $\mathrm{H}_{2} \mathrm{O}_{2}$-mediated cell death in B2-transfected cells. In RGNNV B2-transfected cells, protein B2 induces Drp1-mediated mitochondrial fragmentation and cell death. B2 protein is targeted to the mitochondria via its amino acid targeting signal, ${ }^{41}$ RTFVISAHAA $^{50}$ [27] where it modulates complex II activity, inducing $\mathrm{H}_{2} \mathrm{O}_{2}$ production. In response to the resulting oxidative stress, the expression of antioxidant enzymes that can metabolize the accumulated $\mathrm{H}_{2} \mathrm{O}_{2}$ is upregulated. Finally, cells enter an unbalanced state of higher $\mathrm{H}_{2} \mathrm{O}_{2}$ production, inducing the translocation of the mitochondrial fission factor, Drp1, to the mitochondria, triggering mitochondrial fragmentation and cell death 
B2-induced oxidative stress can up-regulate the antioxidative enzymes, Mn SOD, catalase, and Nrf2, and RGNNV-induced $\mathrm{H}_{2} \mathrm{O}_{2}$ signaling may modulate viral replication in the early and middle stages (24-48 h postinfection). Thus, we propose that the $\mathrm{H}_{2} \mathrm{O}_{2}$ balance is severely disrupted during late replication by viral death inducers $[6,8,22]$ that cause $\mathrm{H}_{2} \mathrm{O}_{2}$ production. During the early and middle replication stages, $\mathrm{H}_{2} \mathrm{O}_{2}$-mediated responses may play a dual role, either enhancing viral replication or modulating the oxidative stress response by up-regulating antioxidant enzymes, such as catalase and $\mathrm{Cu} / \mathrm{Zn}$ SOD [23]. However, the final outcome is dependent on viral death factor expression, such as B2 protein and protein $\alpha$ (capsid protein). In our observation, the advantage of NAC treatment or $\mathrm{Cu} / \mathrm{Zn}$ SOD and catalase expression in blocking-B2 function is greater than the effects on whole viral infection.

$\mathrm{H}_{2} \mathrm{O}_{2}$ production in early embryos expressing $\mathrm{B} 2$ protein increased about 0.3 -fold at $10 \mathrm{hpf}$ and 1.3-fold at $24 \mathrm{hpf}$, which correlated with the increase in $\mathrm{Nrf} 2, \mathrm{Cu} / \mathrm{Zn} \mathrm{SOD}$, Mn SOD and catalase expression at $10 \mathrm{hpf}$, but only catalase at $24 \mathrm{hpf}$, suggesting that these proteins are quickly up-regulated to metabolize ROS. Nrf2 is a cellular sensor of chemical- and radiation-induced oxidative and electrophilic stress [30] and controls the expression and coordinated induction of a battery of defensive genes encoding detoxifying enzymes and antioxidant proteins. However, it is not known whether Nrf2 up-regulated the anti-oxidant enzymes in our system. Although the up-regulation of these genes may help to restore $\operatorname{ROS}\left(\mathrm{H}_{2} \mathrm{O}_{2}\right)$ homeostasis, it did not protect the embryo from damage induced by $\mathrm{B} 2$ overexpression at 10 or $24 \mathrm{hpf}$.

In the present study, B2-induced mitochondrial fragmentation correlated with Drp1 translocation. Mitochondria form a dynamic cellular network that is tailored to the energetic and metabolic requirements of the cell [31, 32]. The morphology of the mitochondrial network within cells represents a delicate balance between fusion and fission events. Proteins involved in both the regulation and maintenance of mitochondrial morphology have crucial roles in maintaining the health of the cell [31, 33]. The master regulator of mitochondrial fission is a largely cytosolic member of the dynamin family of GTPases, Drp1 in mammals and Dnm1 in yeast [34-37]. Drp1 polymerizes into spirals around mitochondria, and through GTP hydrolysis, it constricts the mitochondrion, leading to membrane scission [38-41]. Drp1 activity at the mitochondrial outer membrane is regulated by a variety of posttranslational modifications [42-47] and by interactions with mitochondrial accessory and effector proteins. Changes in Drp1 activity upon phosphorylation may depend on external parameters, such as cell type, age or status, or on internal parameters, such as the localization of Drp1. These kinases phosphorylate and dephosphorylate multiple protein targets, further complicating the interpretation of the role of Drp1 [47].

In our study, B2 protein overexpression induced mitochondrial fragmentation in a homogeneous manner. Such damage was prevented by NAC and the Drp1 inhibitor, Mdivi, which correlated with a reduction in the fragmented mitochondria ratio (Fig. 6B). We also observed increased Drp1 translocation to the mitochondria upon B2 protein expression, which was blocked by NAC and Mdivi. In addition, co-localization of B2 protein and Drp1 was observed at $48 \mathrm{~h}$ post-transfection, indicating that Drp1 translocation is triggered by $\mathrm{H}_{2} \mathrm{O}_{2}$ signaling. Whether phosphorylation or other modifications of Drp 1 occur during this process is still unknown.

In summary, the betanodavirus B2 protein is translocated to the mitochondria via a specific targeting sequencing in its N-terminus (Fig. 7). Once in the mitochondrial matrix, the B2 protein can block complex II function, resulting in loss of mROS homeostasis and depletion of ATP [48]. The increase in $\mathrm{H}_{2} \mathrm{O}_{2}$ causes oxidative stress, leading to the upregulation of antioxidant enzymes and transcription factors, such as Mn SOD, catalase, and Nrf2. Finally, $\mathrm{H}_{2} \mathrm{O}_{2}$ signals can induce the recruitment of the mitochondrial fission protein, Drp1, into the mitochondria, where it participates in mitochondrial fragmentation and triggers oxidative stress-mediated cell death.

Acknowledgments The authors are grateful to Dr. S.C. Chi (Institute of Zoology and Development of Life Science, NTU, Taiwan, ROC) for providing the grouper-fin cell line, GF-1; to Dr. Chang (Institute of Biochemistry, NCKU, Taiwan, ROC) for providing the 293T, HeLa, MCF-7, A549 and H1299 cells; and to Dr. Ken (Department of Biotechnology, NCUE, Changhua, Taiwan, ROC) for providing several vectors (pBudCE4.1-zfCu/Zn SOD and pBudCE4.1-zfCatalase). This work was supported by a Grant awarded to Dr. Jainn-Ruey Hong from the National Science Council, Taiwan, Republic of China (NSC 98-2313-B-006-004-MY3).

Open Access This article is distributed under the terms of the Creative Commons Attribution License which permits any use, distribution, and reproduction in any medium, provided the original author(s) and the source are credited.

\section{References}

1. Ball L, Johnson K (1999) Reverse genetics of nodaviruses. Adv Virus Res 53:229-244

2. Bovo G, Nishizawa T, Maltese C, Borghesan F, Mutinelli F, Montesi F, De Mas S (1999) Viral encephalopathy and retinopathy of farmed marine fish species in Italy. Virus Res 63:143-146

3. Mori KI, Nakai T, Muroga K, Arimoto M, Mushiake K, Furusawa I (1992) Properties of a new virus belonging to nodaviridae found in larval striped jack (Pseudocaranx dentex) with nervous necrosis. Virology 187:368-371

4. Munday B, Kwang J, Moody N (2002) Betanodavirus infections of teleost fish: a review. J Fish Dis 25:127-142 
5. Li H, Li W, Ding S (2002) Induction and suppression of RNA silencing by an animal virus. Science 296:1319-1321

6. Delsert C, Morin N, Comps M (1997) A fish encephalitis virus that differs from other nodaviruses by its capsid protein processing. Arch Virol 142:2359-2371

7. Wu HC, Chiu CS, Wu JL, Gong HY, Chen MC, Lu MW, Hong JR (2008) Zebrafish anti-apoptotic protein zfBcl-xL can block betanodavirus protein alpha-induced mitochondria-mediated secondary necrosis cell death. Fish Shell Immunol 24:436-449

8. Iwamoto T, Mise K, Takeda A, Okinaka Y, Mori K, Arimoto M, Okuno T, Nakai T (2005) Characterization of Striped jack nervous necrosis virus subgenomic RNA3 and biological activities of its encoded protein B2. J Gen Virol 86:2807-2816

9. Su YC, Wu JL, Hong JR (2009) Betanodavirus non-structural protein B2: a novel necrotic death factor that induces mitochondria-mediated cell death in fish cells. Virology 385:143-154

10. Chen LJ, Su YC, Hong JR (2009) Betanodavirus non-structural protein B1: a novel anti-necrotic death factor that modulates cell death in early replication cycle in fish cells. Virology 385: 444-454

11. Lu R, Maduro M, Li F, Li HW, Broitman-Maduro G, Li WX, Ding SW (2005) Animal virus replication and RNAi-mediated antiviral silencing in Caenorhabditis elegans. Nature 436:1040 1043

12. Wang X, Aliyari R, Li W, Li H, Kim K, Carthew R, Atkinson P, Ding S (2006) RNA interference directs innate immunity against viruses in adult drosophila. Science 312:452-454

13. Jellinger KA (2003) General aspects of neurodegeneration. J Neural Transm Suppl 65:101-144

14. Taylor JP, Hardy J, Fischbeck KH (2002) Toxic proteins in neurodegenerative disease. Science 296:1991-1995

15. Krapfenbauer K, Engidawork E, Cairns N, Fountoulakis M, Lubee $\mathrm{G}$ (2003) Aberrant expression of peroxiredoxin subtypes in neurodegenerative disorders. Brain Res 967:152-160

16. Desagher S, Glowinski J, Premont J (1996) Astrocytes protect neurons from hydrogen peroxide toxicity. J Neurosci 16:25532562

17. Dringen R, Hampercht B (1997) Involvement of glutathione peroxidase and catalase in the disposal of exogenous hydrogen peroxide by cultured astroglial cells. Brain Res 759:67-75

18. Schiavone J, Hassan HM (1988) An assay for the detection of superoxide dismutase in individual Escherichia coli colonies. Anal Biochem 168:455-461

19. Shull S, Heintz NH, Periasamy M, Manohar M, Jansen YM, Marsh JP, Mossman BT (1991) Differential regulation of antioxidant enzymes in response to oxidants. J Biol Chem 266:24398-24403

20. Chen SP, Yang HL, Her GM, Lin HY, Jeng MF, Wu JL, Hong JR (2006) Betanodavirus induces phosphatidylserine exposure and loss of mitochondrial membrane potential in secondary necrotic cells, both of which are blocked by bongkrekic acid. Virology 347:379-391

21. Chen SP, Wu JL, Su YC, Hong JR (2007) Anti-Bcl-2 family members, $\mathrm{zfBcl}-\mathrm{x}(\mathrm{L})$ and zfMcl-1a, prevent cytochrome $\mathrm{c}$ release from cells undergoing betanodavirus-induced secondary necrotic cell death. Apoptosis 12:1043-1060

22. Su YC, Hong JR (2010) Betanodavirus B2 causes ATP depletioninduced cell death via mitochondrial targeting and complex II inhibition in vitro and in vivo. J Biol Chem 285(51):39801-39810

23. Chang CW, Su YC, Her GM, Ken CF, Hong JR (2011) Betanodavirus induces oxidative stress-mediated cell death that prevented by anti-oxidants and zfcatalase in fish cells. PLoS ONE 6:e25853

24. Laemmli U (1970) Cleavage of structural proteins during the assembly of the head of bacteriophage T4. Nature 227:680-685
25. Kain S, Mai K, Sinai P (1994) Human multiple tissue western blots: a new immunological tool for the analysis of tissue-specific protein expression. BioTechniques 17:982-987

26. Hong JR, Lin T, Hsu Y, Wu JL (1998) Apoptosis procedes necrosis of fish cell line by infectious pancreatic necrosis virus. Virology 250:76-84

27. Hong JR, Wu JL (2002) Induction of apoptotic death in cells via Bad gene expression by infectious pancreatic necrosis virus infection. Cell Death Differ 9:113-124

28. Hong JR, Lin GH, Lin CJ, Wang WP, Lee CC, Wu JL (2004) The phosphatidylserine receptor is required for the engulfment of dead apoptotic cell and for normal development in zebrafish. Development 131(21):5417-5427

29. Mullen PD, Brand RJ, Parlette GN (1975) Evaluation of dye exclusion and colony inhibition techniques for detection of polyoma-specific, cell-mediated immunity. J Natl Cancer Inst $54: 229-231$

30. Kaspar JW, Niture SK, Jaiswal AK (2009) Nrf 2:INrf2 (Keap1) signaling in oxidative stress. Free Radic Biol Med 47:1304-1309

31. Westermann B (2010) Mitochondrial fusion and fission in cell life and death. Nat Rev Mol Cell Biol 11:872-884

32. Liesa M, Palacin M, Zorzano A (2009) Mitochondrial dynamics in mammalian health and disease. Physiol Rev 89:799-845

33. Chen XJ, Butow RA (2005) The organization and inheritance of the mitochondrial genome. Nat Rev Genet 6:815-825

34. Mozdy AD, McCaffery JM, Shaw JM (2000) Dnm1p GTPasemediated mitochondrial fission is a multi-step process requiring the novel integral membrane component Fis1p. J Cell Biol 151:367-380

35. Otsuga D, Keegan BR, Brisch E, Thatcher JW, Hermann GJ, Bleazard W, Shaw JM (1998) The dynamin-related GTPase, Dnm1p, controls mitochondrial morphology in yeast. J Cell Biol 143:333-349

36. Smirnova E, Griparic L, Shurland DL, van der Bliek AM (2001) Dynamin-related protein Drp1 is required for mitochondrial division in mammalian cells. Mol Biol Cell 12:2245-2256

37. Smirnova E, Shurland D, Ryazantsev SN, van der Bliek AM (1998) A human dynamin-related protein controls the distribution of mitochondria. J Cell Biol 143:351-358

38. Ingerman E, Perkins EM, Marino M, Mears JA, McCaffery JM, Hinshaw JE, Nunnari J (2005) Dnm1 forms spirals that are structurally tailored to fit mitochondria. J Cell Biol 170:1021-1027

39. Lackner LL, Horner LS, Nunnari J (2009) Mechanistic analysis of a dynamin effector. Science 325:874-877

40. Mears JA, Lackner LL, Fang S, Ingerman E, Nunnari J, Hinshaw JE (2011) Conformational changes in Dnm1 support a contractile mechanism for mitochondrial fission. Nat Struct Mol Biol 18:20-26

41. Legesse-Miller A, Massol RH, Kirchhausen T (2003) Constriction and Dnm1p recruitment are distinct processes in mitochondrial fission. Mol Biol Cell 14:1953-1963

42. Taguchi N, Ishihara N, Jofuku A, Oka T, Mihara K (2007) Mitotic phosphorylation of dynamin-related GTPase Drp1 participates in mitochondrial fission. J Biol Chem 282:11521-11529

43. Kim H, Scimia MC, Wilkinson D, Trelles RD, Wood MR, Bowtell D, Dillin A, Mercola M, Ronai ZA (2011) Fine-tuning of Drp1/Fis1 availability by AKAP121/Siah2 regulates mitochondrial adaptation to hypoxia. Mol Cell 44:532-544

44. Cho DH, Nakamura T, Fang J, Cieplak P, Godzik A, Gu Z, Lipton SA (2009) $S$-Nitrosylation of Drp1 mediates beta-amyloid-related mitochondrial fission and neuronal injury. Science 324:102-105

45. Wang H, Song P, Du L, Tian W, Yue W, Liu M, Li D, Wang B, Zhu Y, Cao C, Zhou J, Chen Q (2011) Parkin ubiquitinates Drp1 for proteasome-dependent degradation: implication of 
dysregulated mitochondrial dynamics in Parkinson's disease. J Biol Chem 286:11649-11658

46. Figueroa-Romero C, Iniguez-Lluhi JA, Stadler J, Chang CR, Arnoult D, Keller PJ, Hong Y, Blackstone C, Feldman EL (2009) SUMOylation of the mitochondrial fission protein Drp1 occurs at multiple nonconsensus sites within the B domain and is linked to its activity cycle. FASEB J 23:3917-3927
47. Elgass K, Pakay J, Ryan MT, Palmer GS (2013) Recent advances into the understanding of mitochondrial fission. Biochim Biophys Acta 188:150-161

48. Hong JR (2013) Betanodavirus: mitochondrial disruption and necrotic cell death. World J Virol 2(1):1-5 